\title{
Disciplining the Body: Power and Language in Margaret Atwood's Dystopian Novel The Handmaid's Tale
}

\author{
Maryam Kouhestani \\ PhD student in English Literature, \\ University of Malaya, Malaysia
}

\section{Doi:10.5901/jesr.2013.v3n7p610}

\section{Abstract}

This article explores the effect of power and language in dystopian society. I attempt to show that a novel may be classified as dystopian if it fulfills certain factors that posit language and discourse as fundamental devices of power. These three main factors are as follows: the establishment of an official, totalitarian language, evidence of opposing discourses, and the representation of the characters as a figure who deconstruct social reality.

\section{Introduction}

In The Handmaid's Tale, Atwood depicts a dystopian society. Although many critics regard her novel as a "feminist dystopia"; Atwood denies by saying that writing a dystopian work from a woman's point of view in comparison to all earlier works in this genre written by men does not make her work automatically a "feminist dystopia". Atwood had not intended to write a feminist work, she was interested in totalitarian system which women as margins become the victim of their society. On one hand, The Handmaid's Tale deals with a number of female characters and their circumstances as the margins in society that seems considerable for feminists, on the other hand, she was mainly interested on the destiny of humans in totalitarian conditions not specifically men or women.

The aim of dystopian fiction is to admonish the reader and make them think about all the catastrophes in their society. The Handmaid's Tale definitely works as a tale, where Atwood attempts to warn the reader of the inequalities in our world: the lack of freedom, constant surveillance, antihuman behaviour and fundamental beliefs that are merely some of the misfortunes of our age. A dystopian novel creates an atmosphere of fear and control. Dystopian offers a world where freedom and happiness gains its definition from the totalitarian regime and use or abuse of power are illustrated in different forms. There are various sources of power in the novel such as language, religious authority and control of information. The power through language has great control on the handmaids and like other dictatorship governments, creates an atmosphere of fear in the populace and uses language as an instrument of control. Through the novel, Atwood warns us how the power of language incredibly exploits the minds and disregards the reality.

Atwood composed The Handmaid's Tale with the aim to expose the desperations of people in modern era. The Handmaid's Tale shows a society that is colonized by a Republic that ironically coalesces two extremist ideologies: the Puritanical right that denotes women proper place in the home -like many extremist countries - as the property of men, and the feminist groups that protest against the objectification of women and their bodies under patriarchy. And the fundamental extremists who want to control every aspect of people's life and have constant power on society totalitarian governments.

The story begins with a terrorist attack that kills the President and most Congress, a movement calling itself the "Sons of Jacob" that make a revolution to establish a new republic.

The story is presented from the point of view of a woman called Offred (a patronymic name that means "Of Fred", referring to the man she serves.) The Commander is the high ranking official in Gilead and Offred serves as his Handmaid.

The Handmaid's Tale is a good model of a docile society with the complexities of body image. Atwood uses the female body as a treatment of the mind/body concept and analyses the way in which her character responds to, and resists, its destructive effects. The bodies of women in Atwood's novel such as the handmaids are severely scrutinized to show how a body can be docile. As Foucault introduces, how he sees the human bodies are those accustomed to being disciplined and regarded as docile ones, and human bodies become docile so as to reach the controlling power's goal of order and regulation. That is, the energy of the body is controlled, disciplined and developed and later is reversed to be a 
restraint, a power of subjection.

\section{Docile Body in Gileadean Society}

The women in Gilead like the men are disciplined and organized. They are under the surveillance of the Eyes -Glidean secret police; there are posts everywhere with Guardians and machines that control and supervise everyone; no one is allowed to move freely in the city without passes. The control in Gilead is an extreme form of what Foucault calls a "carceral texture of society [with its] capture of the body and its perpetual observation" (304). The Glidean

Republic, like the prison in Foucault's Discipline and Punish, justifies society's disciplinary technologies and carceral forms. The bodies are controlled both spatially and physically, the female bodies in the novel, whether Wives, the Marthas' or Moira's and Offred's, are by all means docile. As all the Handmaids are the object of surveillance, their movements, bodies, minds and attitudes are the targets of others, including men of different social categories,

Commanders, Guardians, Eyes and women as Aunts, Wives, even the Handmaids' that unwillingly support the system of surveillance by spying on each other.

In Gilead society, femininity is constructed only through the female's self-restraint and purification of the body, wherefore, discipline and punishment are useful for female bodies to make them respectable in male dominated society. In Red Center Offred learns from Aunt Lydia, who reminds all Handmaids "The Republic of Gilead knows no bound. Gilead is within you." (32) This powerful statement indicates how much Offred and other Handmaids internalize the teaching and behave in accordance with other's expectation, for they are forced to remember:

\section{"The posture of the body is important, here and now: minor discomforts are instructive" (89).}

The Handmaid's bodies, furthermore, is turned to one body. In the Red Center the Handmaids are re-educated to reverse their view toward female body as a body of production, body of "freedom to" one body of "freedom from" various things done with body, in other word, from liberated body back to restrained body. Since Gilead's new belief infuses new thought in society, the Aunts teach the Handmaids to recognize their bodies as one unison body that is the property of the nation and a body that is to be given freedom from, rather than a body that is free to do anything.

All the strict control of Gileadean women and in particular Handmaids' mind and body embodies Foucault's theory of disciplinary power and the docile body. Gilead's discipline borrows Foucault's words that "the individual body becomes an element that may be placed, moved, articulated on other. Discipline is no longer simply an art of distributing bodies, of extracting time from them and accumulating it, but of composing forces in order to obtain an efficient machine" (164). In this carceral society in Gilead, as I have attempted to illustrate, women's identities have no meaning; they are completely alienated from their nature and identity. In Gilead's society identities are simplified into few special roles, with each serving only one role and all forming an "efficient machine" of household or procreation.

\section{Power and Language in Dystopian Society}

The Handmaid's Tale is a collection of diaries written by an individual who is restricted in a fundamental regime. Offred uses the language of past that she is used to it, however, the language of the past is an opposing discourse to the new language of the authority. The official language seeks to reject and repress the previous language and replace it with biblical discourse. Gilead as a fundamental regime attempts to abuse the biblical and religious values as their basic ideology to establish the social norms. Offred's diary performs to be an explicit deconstructive scrip of the social and conventional norms that mock the present society through language.

The evident of the official language used in Gilead comes from Offred's commentary and explanation of the new realm. The powerful regime can ignore the past but it is never possible to erase the human memories which serve to threaten the authority. Although actions and deeds can be controlled; minds and thoughts are not a system that can be easily dominated because people are not completely concomitant with the beliefs of the new realms. Aunt Lydia, who instructs and disciplines the handmaids according to the official language, attempts to indoctrinate them the importance of normalizing the regime's idea and belief as something ordinary and acceptable. "Ordinary, said Aunt Lydia, is what you are used to. This may not seem ordinary to you now, but after a time it will. It will become ordinary" (Atwood 43). The official language must be accepted as normal and ordinary discourses and women whether to be Handmaids, Marthas, Econowives or Jezebels are forced to act according to the norms. The regime acknowledges them that ideal future will be gained when women accept the norms and attempt to forget their past. In this case, Aunt Lydia tries to persuade the handmaids as the transitional generation that should accept the new belief system: "You are a transitional generation. It 
is the hardest for you. We know the sacrifices you are being expected to make. It is hard when men revile you. For the ones who come after you, it will be easier. They will accept their duties with willing hearts." (127)

In Foucault's term, knowledge is power and power has control over knowledge, therefore the Republic forces the transitional generation to gradually accept the ideal system of the Republic. The regime believes in future they will have ultimate control over the past generation's thought and belief in order to disempower their attack against the official language. As a means to gain the power of language, the authority manipulates the language for their own purposes. For instance, Gilead believes the kind of freedom existed in past was some of the reasons that anarchy occurred. Aunt Lydia tells the handmaids: "There's more than one kind of freedom, freedom to and freedom from. In the days of anarchy, it was freedom to. Now you are being given freedom from. Don't underrate it." (34)

By underestimating discourses of the past, the Republic can control and reinforce the language. As a matter of fact, language is the foundation for thoughts and those who can control the language can also restrict the thought, therefore the concept of "freedom" in Gilead for future generation will only exist as "freedom from". "Freedom to" which is the concept of freedom we know it, will no longer exist and the usage of the word "freedom to" will be strictly forbidden in future generation.

Gilead, also denies literacy for all women to have a permanent control on them. The regime forbids all literature and replaces it with biblical stories read by Commander. It is not possible for power to be exercised without knowledge; it is not possible for knowledge not to engender

power." (Power 52) No handmaids and apparently any other women are allowed to read and write, because the knowledge can empower them to resist against the rules. Therefore, the Republic keeps women at an appropriate level of subservience. These rules indicate that those who have control over the words and language have dominant power. For those who cannot read and write, there is no form of communicating that opposes the authority's belief and no form of thinking other than what the regime learns them to believe. Offred is consciously aware of the power of words and language: "[The Commander] has something we don't have, he has the word. How we squandered it once." (Atwood 99) However, words provoke discourses based on knowledge of the past and afford power, knowledge and power that are integrated with one another (Power 52); the only way to reinforce the power on generations.

Offred consciously deconstructs the social reality through her narrative discourses. She is aware of the power that surrounds them and produces knowledge, the knowledge that reinforces the power. Her narrative becomes a weapon to keep her sanity and struggle against the perpetual rules. For this reason, she narrates the situation as there is someone to hear and respond one day: "But if it's a story, even in my head, I must be telling it to someone. You don't tell a story only to yourself. There's always someone else." (Atwood 49) Offred tells her story because she knows that one day it will be heard. She knows that those who will hear her story will be beyond the Gileadean reign of power and will truly judge the regime. She knows it will be difficult for the future to believe this story as sometime real: "If it's a story I'm telling, then I have control over the ending. Then there will be an ending, to the story, and real life will come after it. I can pick up where I left off. It isn't a story I'm telling" (49)

Then Offred expresses that writing is something forbidden in the regime and the only way to communicate with the future generation is narrating her terrible story: "Tell, rather than write, because I have nothing to write with and writing is in any case forbidden." (49)

Therefore, she uses the power of language and words through narrating her story. She has strict control over her own language; however, she is aware that she is completely powerless in the Gileadean hierarchy. She believes if she chooses certain words, she will be able to achieve the meaning that will connect her to former self and reveal the situation of the new society. For instance, Offred refuses to say "my" room when she is compelled to live in the Commander's house, it is the way she rejects the social expectations and standards. The word "my" relates to some personal belonging, and "my room" means my privacy. She believes there is no privacy in Commander's house and she does not belong to that place, this is the way she attempts to hold on her former beliefs. In this way she shows the difference between her new society and former life. In contrast, Offred takes official words, such as "household" rather than "family", she finds the word "family" an intimate relationship between its members, which does not make sense in the new society: "Household: that is what we are. The Commander is the head of the household. The house is what he holds. To have and to hold, till death do us part. The hold of a ship. Hollow. (91) Offred alters the meanings of words so that the words lose their authority, in this way she has control over words and uses the power of language to deny the social standards. With using the power of language, Offred challenges the Gileadean official language and tries to survive herself both mentally and emotionally: "There are the kinds of litanies I use, to compose myself." (120)

Offred realizes, what is between knowledge and power is the issue of discourse. Power is held by those who create context and context is based on language, where language is related to the organization and regulation of 
knowledge. The relationship between discourse, context and knowledge creates power. Offred is aware of this relationship between knowledge and power, because she examined two different ideologies, her former life and the new society that forces her to accept the standards.

In The Handmaid's Tale, Atwood depicts a society which establishes a rigid social belief through the domination of language. However, Offred, the protagonist deconstructs the language because she is not bounded to the struggle for domination of language and has control over the social reality. Offred narrates her diary in a language of the past and in this way she explores the opposing discourse to resist against the social authority. Therefore, regardless to what level of power the society achieves by the end of the novel power is undermined through the words and discourses of language used by the narrator. The reader also realizes the reality of Gileadean society through the leaning experience of the narrator. The Handmaid's Tale as a dystopian novel depicts a society that intends to achieve an ideal system of belief by empowering its own language and discourse and repressing other languages. Within this society, Offred, the narrator reveals the role of power and the real truth of the regime through language and discourses.

\section{Conclusion}

Margret Atwood claims: "There's not a single detail in the book that does not have a corresponding reality, either in contemporary conditions or historical fact" (McCombs 284). There are many totalitarian societies in the world, communist or religious extremist societies which have constant control on their citizens' mind and behaviour through the power of language.

Through dystopias the author makes the readers to think about the hidden dangers in the society where they live. The main concerns in Atwood's novel are relevant for the readers of today exactly due to the fact that they draw connections between democratic and totalitarian world orders and demonstrate what may happen if certain trend, that may lead to totalitarianism remains unnoticed in a democratic society. For Atwood language in addition to being a means of communication is also something one can use to execute power -to pursue their personal interests and show competence and control in a specific field of life. The use of language as a means to execute power and as a means through which to gain ultimate power is one of the central themes in The Handmaid's Tale to illustrate our modern society.

In The Handmaid's Tale Atwood reveals, however there are close relations between power and language but there are some ways to cross these borders and to change the positions in the power hierarchy.

\section{Reference}

Atwood, Margaret. The Handmaid's Tale. London: Vintage Books, 1996.

Foucault, Michel. Discipline and Punish: The Birth of the Prison. New York: Vintage Books, 1995.

Gordon, Colin. Power and Knowledge: selected interviews and other writings, 1972-1977. Harvester Press, 1980

Harold, Bloom. Margaret Atwood's The Handmaid's Tale. Chelsea House Publishers, 2004.

Judith, McCombs. Critical Essays on Margaret Atwood. G.K. Hall, 1988. 